\title{
The Presence and Level of Immunosuppresive Factor (Alpha-1-Acid Glycoprotein) in the Seminal Plasma from Males of Fertile and Infertile Couples
}

\author{
Arjatmo Tjokronegoro, dr, PhD"; Djasmoro Ariguno, Drs "*
}

\section{Abstrak}

Plasma semen mengandung faktor imunosupresif yang mampu melindungi sel-sel sperma dari kerusakan imunologik dan mencegah baik pria maupun wanita tersensitisasi dengan antigen spermatozoa. Perlindungan terhadap sel-sel sperma dari respons imun pria dan wanita sangat penting untuk keberhasilan konsepsi. Faktor-faktor ini dapat mencegah terjadinya pembentukan antibodi antisperma, baik dalam tubuh pria maupun wanita. Salah satu faktor ini, yang dikenal sebagai alfa-1-asam glikoprotein diselidiki pada penelitian ini. Keberadaan dan kadar alfa-1-asam glikoprotein di dalam plasma semen dari pria-pria infertil maupun fertil diukur dengan metode imunologik, kemudian efeknya terhadap motilitas spermatozoa diobservasi. Plasma semen diperoleh dari 20 pria fertil dan 50 infertil dan pengamatan terhadap alfa-1-asam glikoprotein dilakukan dengan teknik radial imunodifusi. Hasil yang diperoleh memperlihatkan bahwa substansi ini ada dalam setiap cairan plasma semen. Namun demikian kadar rata-ratanya dalam dua kelompok pria itu, fertil dan infertil, berbeda nyata, yaitu berturut-turut $2.39 \mathrm{mg} / \mathrm{dl}$ dan $1.87 \mathrm{mg} / \mathrm{dl}(\mathrm{t}=2.73$; alfa $=0.05)$. Kadar alfa-1-asam glikoprotein lebih rendah pada kelompok pria infertil daripada pada pria fertil. Infertilitas dapat disebabkan oleh banyak faktor, satu di antaranya ialah adanya antibodi antisperma, yang dapat mempengaruhi kecepatan sperma bergerak. Produksi antibodi semacam itu dapat ditekan oleh adanya faktor imunosupresif dalam plasma semen. Bila substansi semacam itu rendah, antibodi antisperma dapat timbul yang disebabkan oleh respons imun terhadap autoantigen sperma yang kemudian mempengaruhi pergerakan spermatozoa sehingga menyebabkan kemandulan. Tetapi dalam penelitian ini ditemukan hasil yang lain, yaitu tidak ada perbedaan antara kadar alfa-1-asam glikoprotein pada kedua kelompok pria terhadap kecepatan gerak spermatozoa. Agaknya keberadaan substansi semacam itu tidak dapat dipakai sebagai indikator dalam menentukan status fertil dan infertil seorang pria, karena pengaruh aktivitas imunosupresif plasma semen terhadap motilitas sperma tidak nyata.

\section{Abstract}

Seminal plasma contains immunosuppresive factors, which protect the sperm cells from immunological injury and prevent the male as well as female organism from being sensitized by spermatozoal antigens. Protection of the sperm cells from the male and female organism's immune response is important for sucessful conception. These factors could prevent the production of antisperm antibodies, either in the male and female body. One of these factors which is known as alpha-1-acid glycoprotein was investigated in this study. The presence and level of alpha-1-acid glycoprotein in the seminal plasma from males of infertile and fertile couples were measured by immunological method, and then the effect on the spermatozoa motility was observed. Seminal plasma were obtained from 20 fertile and 50 infertile males and the observation toward alpha-1-acid giycoprotein was done by means of radial immunodiffusion technique. Results obtained showed that this substance is present in every seminal plasma specimen. However the mean level in the two male groups, fertile and infertile, were significantly different, i.e $2.39 \mathrm{mg} / \mathrm{dl}$ and $1.87 \mathrm{mg} / \mathrm{dl}$ respectively $(t=2.73 ;$ alpha $=0.05)$. The level of alpha-1-acid glycoprotein was lower in the infertile males compared to the fertile males. Infertility could be due to many factors, one of these are the presence of antisperm antibodies which could influence the velocity of the sperm's movement. The production of such antibodies could be suppress by the presence of immunosuppresive factor in the seminal plasma. If such substance is low, the antisperm atibody could occured due to the immune reponse toward the sperm autoantigen and eventually influence the motility as well as the capacity of the spermatozoa, rendered them infertile. However in this investigation the results were different, i.e. there was no difference between the alpha-1-acid glycoprotein level of the two groups of the spermatozoa speed movement. It seems that the presence of such abstance could not be used as an indicator for the fertile and infertile status of the male, as that the influence of immunosuppresive activity of seminal plasma on the motility of sperm is not obvious.

Ergwords: Immunosuppresive factor,Alpha-1-acid glycoprotein, Human seminal plasma, Infertile and fertile male 


\section{INTRODUCTION}

Infertility presents a fairly complex problem to husband-wife couples. The production of antisperm antibody in the reproductive fluids could be the possible cause, since seminal plasma and spermatozoa are antigenic for both male and female. ${ }^{1}$ In 1959 , Rumke and Hellinga ${ }^{2}$ have stated that antisperm antibodies could cause several manifestations such as sperm agglutination, immobilization, and cytotoxicity, rendering the spermatozoa incapable of fertilizingthe ovum and causing infertility. Similar results were also observed by Hanafiah et al. ${ }^{3}$

Although sperm possesses a 'non-self antigen' that can easily, from time to time, stimulate the formation of antibodies against the spermatozoa, the fact remains that there are still many males whose seminal plasma do not contain such antibody. ${ }^{4,5}$ This situation could probably due to the presence of various immunosuppressive factors in the seminal plasma. ${ }^{6,7}$ It seems that these factors are capable of preventing immune responses against the spermatozoa antigen in male as well as in female body. One of the factors with this immunosuppressive characteristic is alpha-1-acid glycoprotein. ${ }^{8,9}$ Since 1977 , Sayce and Rees ${ }^{8}$ have reported that $14 \%$ of 100 subfertile males were found to have high level of alpha-1-acid glycoprotein in their seminal plasma.

In view of the role of the immunosuppressive factors, especially alpha-1-acid glycoprotein in the male seminal plasma, this study was conducted. The purpose of this investigation was to determine whether such substance was present in every seminal plasma, and whether it is different between two groups of males, fertile and infertile couples. If it is present in all seminal plasma observed, it should be questioned whether the alpha-1-acid glycoprotein level in the seminal plasma of infertile males is lower than that of fertile males. Should the substance level be lower, then it may be possible that the formation of autoantibodies have taken place, and as a result the spermatozoa from the male would then be unable to fertilize his wife's ovum. If there is any correlation between the level of alpha-1-acid glycoprotein, we would like to know also whether in the infertile males, the alpha-1-acid glycoprotein level is different between the two groups of sperm velocity, the slow and the fast movement. Due to the low level of this substance, the antisperm antibody will probably be produce, and eventually could be predict to influence the movement of spermatozoa and render them infertile.

\section{MATERIALS AND METHODS}

In this investigation semen analysis of males of 20 fertile and 50 infertile couples have been conducted, and the alpha-1-acid glycoprotein of the seminal plasma have been observed and measured. The male of fertile couples as the control, were volunteers whose wife are already pregnant or have delivered one or more children whose age varied from new born to 3 years. The infertile males were from the patients who came for andrologic examination at the Department of Medical Biology Faculty of Medicine University of Indonesia, Jakarta, Indonesia. The age of all males examined was between 20 and 50 .

The semen was obtained through masturbation and collected in a clean glass bottle. The abstinence time was 3 to 5 days. The semen was kept for 20 minutes to liquify and then a drop of semen was transferred to a counting chamber (Improved Neubauer type, England), and covered with a cover glass. Under a light microscope, the spermatozoa movement was observed and the speed of movement was measured using a stop watch. The speed of 25 sperms that were able to cross a $1 / 20 \times 1 / 20 \mathrm{~mm}$ area of the counting chamber was measured and then the mean speed was calculated. The boundary between slow and fast movement of the spermatozoa was determined at 1.2 seconds per $1 / 20 \mathrm{~mm}$.

The alpha-1-acid glycoprotein level of the seminal plasma was measured by a radial immunodiffusion technique. ${ }^{10}$ The seminal plasma was separated from the spermatozoa by centrifugating the semen at a speed of $1000 \mathrm{~g}$ for 15 minutes. The seminal plasma was then separated from its sediment (sperm, debris, white blood cell etc) and stored in the refrigerated $\left(20^{\circ} \mathrm{C}\right)$ until used. The radial immunodiffusion plates were made of plastic measuring $7.0 \times 2.0 \mathrm{~cm}$. Three milliliters of Noble Agar $1 \%$ (in $0.9 \% \mathrm{NaC} 1$ ), already mixed with $60 \mu \mathrm{l}$ of specific antibody solution against alpha-1-acid glycoprotein (Behring, Germany), was then poured onto a plate. After the agar had hardened, 6 wells of $3 \mathrm{~mm}$ diameter each were made in it. A standard concentrated of serum solution (Behring, Germany) containing $103 \mathrm{mg} / \mathrm{dl}$ alpha-1-acid glycoprotein was diluted with $0.9 \% \mathrm{NaCl}$ solution to ratios of $1: 32,1: 64$, and $1: 128$. These 3 different concentrations of standard serum containing alpha-1-acid glycoprotein were sequentially inserted into 3 wells using a Pasteur pipette. The quantity of standard serum inserted into each well was $10 \mu$ l. Into the remaining 3 wells of each plate the seminal plasma samples with unknown alpha-1-acid glycoprotein levels were then inserted, about $10 \mu \mathrm{l}$ for each well. Each sample was always duplicated. 
To determine whether the alpha-1-acid glycoproteein level in the seminal plasma from males of fertile and infertile couples differed significantly, a statistical Student's t test was conducted. ${ }^{11}$

Further observation was also carried out to find out whether there was a difference in the alpha-1-acid glycoprotein levels of the infertile semen with different speed of the spermatozoa movement i.e. below 1.2 seconds and above 1.2 seconds per $1 / 20 \mathrm{~mm}$. This observation was done under the microscope and the velocity of the sperm's movement was measured by using a stop watch; the results were compared to the alpha-1-acid glycoprotein contents of the seminal plasma.

\section{RESULTS}

The mean levels of alpha-1-acid glycoprotein from the 20 seminal plasma samples of fertile males and from the 50 seminal plasma samples of infertile males was $2.39 \mathrm{mg} / \mathrm{dl}$ and $1.87 \mathrm{mg} / \mathrm{dl}$ respectively. The complete results can be seen in Table 1. By means of a statistical Student's $t$ test it became apparent that the alpha-1acid glycoprotein content of the seminal plasma in the fertile males differed significantly from that of the infertile males $(\mathrm{t}=2.73$; alpha $=0.05)$. This substance was higher in the male of the fertile group.

To evaluate the influence of the alpha-1-acid glycoprotein, directly as well indirectly via the antisperm antibody activities, the speed of spermatozoa movement was investigated. The semen of infertile males were divided into 2 groups, i.e. those with an average speed of sperm movement below 1.2 seconds and those whose average sperm movement speed was above 1.2 seconds per $1 / 20 \mathrm{~mm}$. Each group comprised 30 samples, and the results can be seen in Table 2. It was apparent that the mean level of alpha-1-acid glycoprotein in the 2 groups of spermatozoa movement did not differ significantly, i.e. $1.99 \mathrm{mg} / \mathrm{dl}$ and 1.76 $\mathrm{mg} / \mathrm{dl}$ respectively $(\mathrm{alpha}=0.05)$.

\section{DISCUSSION}

From the data showed on Table 1 and the statistical analysis indicate that the infertile males have a different mean level of alpha-1-acid glycpoprotein content from fertile males; it was obvious that the level in the infertile males was lower than in the fertile males. This examination proved that the alpha-1-acid glycoprotein factor can be found in every seminal plasma and that a difference in the alpha-1-acid glycoprotein content between the two male groups could possibly play a role in the fertility status of the males.
Table 1. Alpha-1-acid glycoprotein level in the seminal plasma from males of fertile and infertile couples

\begin{tabular}{|c|c|c|}
\hline \multirow{2}{*}{$\begin{array}{c}\text { Samples } \\
\text { no: }\end{array}$} & \multicolumn{2}{|c|}{ Alpha-1-açid glycoprotein (mg/dl) } \\
\hline & Fertile males & Infertile males \\
\hline 1 & 2.55 & 1.30 \\
\hline 2 & 2.00 & 2.40 \\
\hline 3 & 2.00 & 2.65 \\
\hline 4 & 2.00 & 2.55 \\
\hline 5 & 2.00 & 1.45 \\
\hline 6 & 1.60 & 2.25 \\
\hline 7 & 2.00 & 2.20 \\
\hline 8 & 2.70 & 0.75 \\
\hline 9 & 3.00 & 0.95 \\
\hline 10 & 2.00 & 2.35 \\
\hline 11 & 2.55 & 2.85 \\
\hline 12 & 2.55 & 1.20 \\
\hline 13 & 4.00 & 1.15 \\
\hline 14 & 1.60 & 1.20 \\
\hline 15 & 2.40 & 2.90 \\
\hline 16 & 2.55 & 2.30 \\
\hline 17 & 3.00 & 1.10 \\
\hline 18 & 1.50 & 2.60 \\
\hline 19 & 2.45 & 1.25 \\
\hline 20 & 3.25 & 0.45 \\
\hline 21 & - & 2.45 \\
\hline 22 & - & 0.85 \\
\hline 23 & - & 0.80 \\
\hline 24 & - & 1.60 \\
\hline 25 & - & 2.90 \\
\hline 26 & - & 0.90 \\
\hline 27 & - & 1.55 \\
\hline 28 & . & 1.55 \\
\hline 29 & . & 2.00 \\
\hline 30 & - & 1.55 \\
\hline 31 & - & 3.20 \\
\hline 32 & - & 2.10 \\
\hline 33 & - & 1.35 \\
\hline 34 & . & 3.20 \\
\hline 35 & - & 3.40 \\
\hline 36 & - & 1.30 \\
\hline 37 & - & 2.70 \\
\hline 38 & - & 3.15 \\
\hline 39 & - & 1.40 \\
\hline 40 & - & 1.95 \\
\hline 41 & - & 1.70 \\
\hline 42 & - & 2.20 \\
\hline 43 & - & 2.20 \\
\hline 44 & - & 1.60 \\
\hline 45 & - & 1.60 \\
\hline 46 & - & 2.70 \\
\hline 47 & - & 2.70 \\
\hline 48 & - & 2.00 \\
\hline 49 & - & 1.45 \\
\hline 50 & - & 1.20 \\
\hline Total sample : & 20.00 & 50.00 \\
\hline Mean level : & 2.39 & 1.87 \\
\hline Range : & $1.5-4.0$ & $0.45-3.20$ \\
\hline Mode & 2.00 & 1.20 \\
\hline \multicolumn{3}{|l|}{ Standard } \\
\hline deviation : & 0.61 & 0.75 \\
\hline
\end{tabular}


Table 2. Alpha-1-acid glycoprotein level of the seminal plasma from males of infertile couples with a sperm speed below 1.2 seconds and above 1.2 seconds per $1 / 20 \mathrm{~mm}$

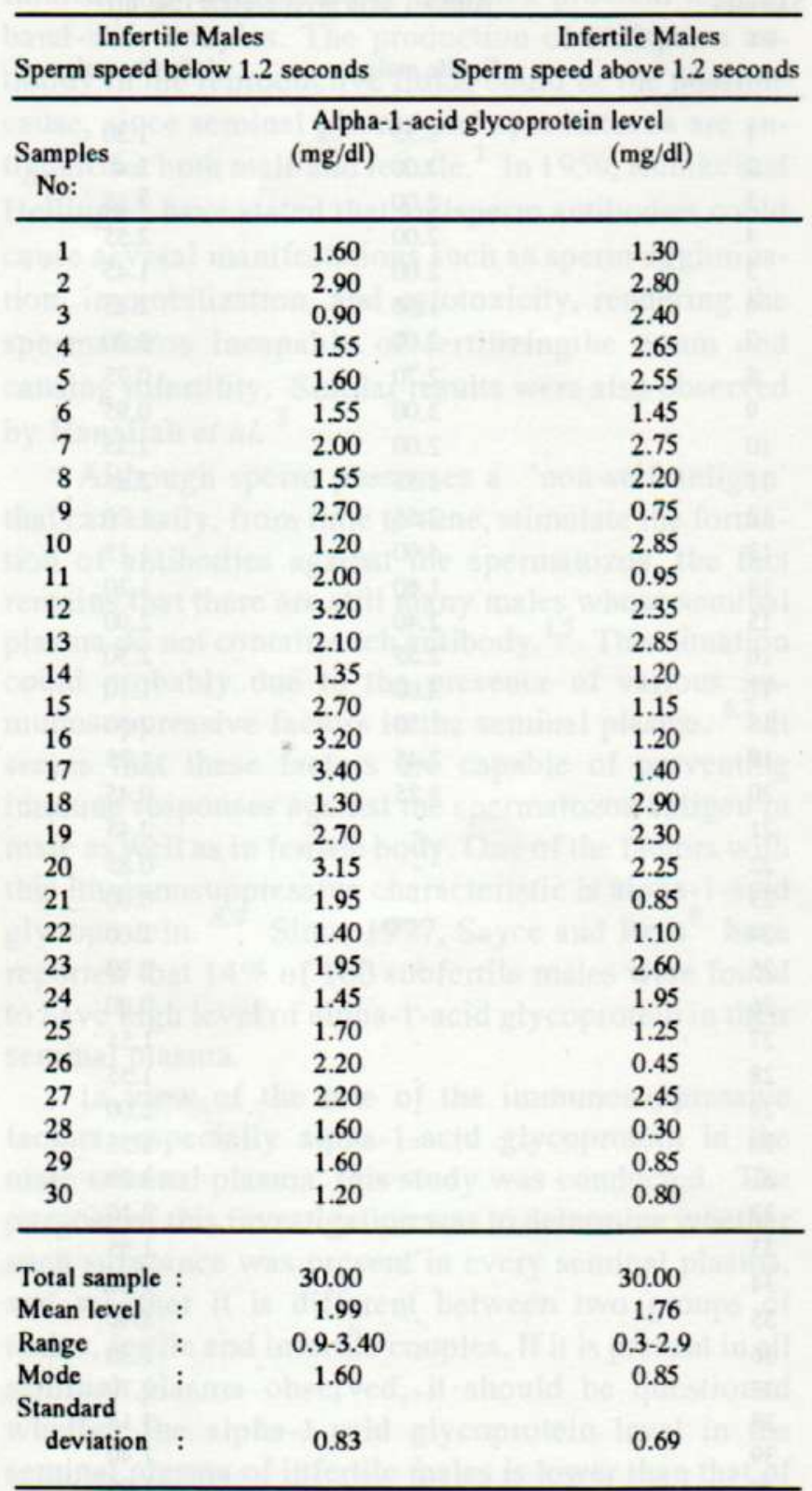

According to Michael ${ }^{9}$ and Lord et al. ${ }^{12}$, alpha-1- acid glycoprotein can act as an immunosuppressive factor that is capable of inhibiting the formation of antisperm antibodies. Uehling ${ }^{10}$ ini 1971 observed that' such antisperm antibodies can be produced locally in the reproductive tract. Thus it is possible that the presence of a higher level of alpha-1-acid glycoprotein could probably prevent the production of such local antibody formation in the reproductive tract. This observation agrees with the opinion of Lord et al ${ }^{12}$ that in the seminal plasma there are certain factors which actively suppress the immune response activity.
On the other hand, in the infertile males where the alpha-1-acid glycoprotein level is low, the formation of antisperm antibodies could possibly occured. When formed, this antibody will subsequently inhibit the movement of spermatozoa, resulting in failure to fertilize the wife's ovum. ${ }^{13}$

According to James and Hargreave ${ }^{7}$ it was concluded that the immunosuppressive activities of the seminal plasma is not only due to one factor alone, i.e. alpha-1-acid glycoprotein factor, but there are other factors as well. These are, for instance, pregnancy associated protein A-like molecule (PAPA), proteinfixed $\mathrm{Fc}$ receptor, uteroglobuline, transglutaminase, prostaglandin, etc. Based on this, we can explain as why are the results of the alpha-1-acid glycoprotein level in the seminal plasma of several fertile males (i.e. no. $6,14,18$; see Table 1) showed relatively low levels, i.e. below $1.60 \mathrm{mg} / \mathrm{dl}$ in contrast to the average level $(2.39 \mathrm{mg} / \mathrm{dl})$. Eventhough the alpha-1-acid glycoprotein level in the 3 fertile males is low, it is possible that the activity of the overall immunosuppressive factors was quite high.

The high level of alpha-1-acid glycoprotein in the seminal plasma is useful not only in the male body but also in the wife's body, i.e. in the reprcductive tract. As we already know, the female body is also capable of forming an antibody response locally towards the male spermatozoa, so that the vaginal and the cervical environment become hostile to the spermatozoa. ${ }^{14}$ However, Lord et al ${ }^{12}$ have stated that the immunologic response against the spermatozoa components in the female reproductive tract can be broken by immunosuppressive factors originating from the seminal plasma.

Anderson and Tarter ${ }^{6}$ in 1982 have put forward various hypotheses as to how immunosuppressive factors in the seminal plasma can function properly:

1) the immunosuppressive factor is able to wrap around the spermatozoa surface, as if covering the antigen sperm with an immunologic system against an exposure.

2) the immunosuppressive factor is capable of changing the antigenic structure of the surface of the spermatozoa, probably enzymatically, so that it is no longer a non-self antigen.

3) the immunosuppressive factor wrapped around the spermatozoa can be released and react with lymphocytes or macrophages, preventing these cells from performing their immune functions.

Michael $^{9}$ in 1980 has proven that the seminal plasma is capable of inhibiting the mitogenic response against concanavalin $\mathrm{A}$, as well as inhibiting the induction of the cytolytic lymphocyte reaction against an alloantigen. 
Table 2 shows that the level of alpha-1-acid glycoprotein was the same in the two groups of infertile semen samples differing in the speed movement of the spermatozoa. This means that the alpha-1-acid glycoprotein level, both directly and indirectly, i.e. via the formation of the antisperm antibodies, did not influence the movement of the spermatozoa. At first it was thought that when the antisperm antibody could be formed, especially in the absence or low level of the alpha-1-acid glycoprotein factor with its immunosuppressive characteristic, the antibody would then react on the motile spermatozoa. This would result in the inhibition of the sperms' movement, making it extremely slow, possibly below 1.2 seconds per $1 / 20 \mathrm{~mm}$, or even making the spermatozoa entirely stationary. In this investigation, however, it is apparent that the alpha-1-acid glycoprotein levels of the 2 infertile male groups did not differ significantly.

This condition may be due to several possibilities. Firstly, the level of the alpha-1-acid glycoprotein factor was not high enough to influence the production of antisperm antibody. Secondly, eventhough the production is occured the function to immobilize the spermatozoa is low and only enough to agglutinate the spermatozoa. Thirdly, it is possible that the speed of the motile spermatozoa was related more to the energy-sources in the seminal plasma, such as fructose. ${ }^{15}$ Soehadi et al ${ }^{16}$ said that spermatozoa which lack energy will move weakly, less than 1.2 second per $1 / 20$ $\mathrm{mm}$.

The role of the immunosuppressive factors, such as the alpha-1-acid glycoprotein in the male as well as in the female reproductive tract is still quite important. It seems that such factors are needed in the male body in order to inhibit the production of autoantibodies against its own spermatozoa. Nature apparently has provided factors to neutralize this process, so that in normal condition there are no such antibodies present in the male ejaculate. ${ }^{17}$ On the other hand, these immunosuppressive factors of the seminal plasma are beneficial for the female reproductive tract as well as they can neutralize the formation of antisperm antibodies in the female body. ${ }^{13}$ In the unexplained infertility cases, a large amount of antibodies against spermatozoa is found in both male and female body, either in their reproductive secretion as well as in their blood serum. ${ }^{14,18}$ At this particular point questions should be raised. Is this situation really due to to the presence or absence of the alpha-1-acid glycoprotein in the reproductive tract? Or are there any other factors which could play a role as the immunosuppresive factors ? To answer this question, further research has to be done because in this investigation the data showed that even alpha-1-acid glycoprotein is present in every seminal plasma observed, the immunosuppresive activity was not obvious.

\section{REFERENCES}

1. Quinlivan WLG, Sullivan, H. Antispermatozoal effects of human seminal plasma: An immunologic phenomenon. Fertil Steril 1976; 2: 1194-8.

2. Rumke $P$, Hellinga G. Autoantibodies against spermatozoa in sterile men. Amer J Clin Pathol 1959; 32: 357-63

3. Hanafiah MJ, Epstein JA, Sobreno, AJ. Sperm agglutinating antibodies in 263 infertile couples. Fertil Steril 1972; 23 : 493-7.

4. Tjokronegoro A. The immunological aspects of male reproductive system. In: Spermatology (ed. Soehadi K), Surabaya: The Indonesian Society of Andrology, 1978: 337 50 (Indonesian).

5. Bronson R, Cooper G, Rosenfeld D. Sperm antibodies: their role in infertility. Fertil Steril 1984; 42: 171-83.

6. Anderson DJ, Tarter TH. Immunosuppressive effects of mouse seminal plasma component, in vivo and in vitro. J Immunol 1982; 128: 535-39.

7. James K, Hargreave, TB. Immunosuppression by seminal plasma and its possible clinical significance. Immunol Today $1984 ; 5:$ 357-63.

8. Sayce R, Rees RC. Human seminal orosomucoid and its possible use in medicolegal investigation. Med Sci Law 1977; 17: 282-8.

9. Michael B. Immunosuppression by human plasma alpha-1acid glycoprotein: Importance of the carbohydrate moeity. Proc Natl Acad Sci USA 1980; 7: 6109-33.

10. Uehling D T. Secretory immunoglobulin A in seminal fluid. Fertil Steril 1971; 22: 769-73.

11. Daniel WW. Biostatistics: a foundation for analysis in the health sciences. New York: John Wiley \& Sons, 1987

12. Lord EM, Sensabauch GF, Stites DP. Immunosuppressive activity of human seminal plasma. I. Inhibition of in vitro lymphocyte activation. J Immunol 1977; 118: 1704-11.

13. Kelly RW. Seminal plasma immunosuppresive activity: the achilles heel of reproduction. Internat J Andrology 1991; 14: 243-7

14. Telang M, Reynak JV, Shulman S. Antibodies to spermatozoa: Correlation of sperm antibodies activity with postcoital test in infertile couple. Internat J Fertil 1978; 23: 200-6.

15. Hartamto $\mathrm{H}$. The role of seminal plasma on the sperm motility. Medika 1982; 8: 355-7 (Indonesian).

16. Soehadi K, Santoso KH, Halim J. The investigation of spermatozoa motility with the microcinematography method. Indon J Med Assoc 1982; 8: 104-11 (Indonesian).

17. Tjokronegoro A, Sosroatmodjo S, Sudoyo HA, Herman R et al. Immunoandrology: A new development in the field of male reproduction (Part 3). Medika 1978; 4 : 398-404 (Indonesian).

18. Soebroto SO, Sudoyo HA, Moeloek N, Tjokronegoro A. The correlation between antisperm antibodies in the serum and the spontaneus sperm agglutination. Indon $\mathrm{J}$ Med Assoc 1984; 10:95-6 (Indonesian). 